\title{
Livsoplysning og livsfilosofiske perspektiver - et uddannelsesmassigt modsvar til tidens fokus på kompetenceudvikling
}

\author{
Af Lene Frølund Thomsen
}

Regner Birkelund: Livs-Oplysning. Gyldendal, København, 1999. 232 sider. Regner Birkelund (red.): Eksistens og livsfilosofi. Gyldendal, København, 2002. 40 sider.

I en Chaplin-film udspiller sig følgende lille scene: Som sædvanlig er Chaplin uden penge, han går derfor hen til en pantelåner for at låne penge på sit ur. Pantelåneren ser skeptisk på uret og begynder så ellers systematisk at skille det ad - alt bliver pillet fra hinanden. Til sidst ryster han på hovedet og siger, at det ur kan han ikke give noget for - ingen af delene er noget værd.

Med denne lille historie får vi et illustrativt billede på de tendenser, der siden 1970'erne har præget den herskende pædagogiske tradition herhjemme: den såkaldte erfarings- eller frigørelsespædagogik, der har rod i Frankfurterskolen og Kritisk Teori, og som rækker tilbage til oplysningstidens frihedsidealer. Frigørelsespædagogikken har, på baggrund af et fornuftsbåret videnskabsbaseret verdenssyn, haft som sin primære målsætning at udvikle elevernes kritiske sans - de har skullet lære at pille tingene fra hinanden (som pantelåneren) frem for at få styrket sansen for de livsmæssige helheder og sammenhænge. Man har primært været optaget af at skabe selvstændige, (for)handlingsdygtige og frigjorte borgere, der besidder evnen til at gennemskue og beherske. Kort sagt: moderne pædagogik har ensidigt prioriteret den politiske opdragelse - dvs. udviklingen af det demokratiske sindelag på bekostning af det filosofiske sindelag, der handler om stræben efter visdom og samtalen om det gode liv.

Det er stadig frigørelsespædagogikken, der i altovervejende grad sætter dagsordenen i den aktuelle uddannelsespolitiske debat, og inden for de senere år har man kunnet iagttage, at den har skrevet sine idealer ind i særligt ét begreb, der som et næsten helligt mantra er kommet til at tegne tidsånden. Begrebet hedder kompetenceudvikling, og det omtales - inden for den aktuelle uddannelsestænkning - i snart sagt enhver tænkelig afskygning: vi hører om handlekompetence, læringskompetence, forandringskompetence, relationskompetence, meningskompetence etc. Kompetenceudvikling er - med andre ord-blevet senmodernitetens svar på, hvordan individet kan lære at bringe sig på højde med udviklingen $\mathrm{i}$ et komplekst og hastigt foranderligt videns- og 
informationssamfund, der stiller krav om effektivitet, styring, omstillingsparathed og fleksibilitet.

Går man til benet af det pædagogik- og menneskesyn, som kompetencefilosofien - og dermed de herskende uddannelsespolitiske tendenser - afspejler, så kan man iagttage to ting: For det første er begrebet kompetence knyttet til individet og individets personlige udvikling, præsteren, kunnen og viden, hvilket vil sige, at kompetencefokuseringen afspejler de stigende individualiseringstendenser - og kravet om handling - som præger tiden helt generelt. Dernæst hviler kompetencebegrebet overvejende på rationelle nytte-betragtninger og mål-middel overvejelser à la: hvordan udnytter man mest optimalt de menneskelige ressourcer?

Laust Riis-Søndergaard, der er redaktør på Højskolebladet, spidsformulerer kritikken af den aktuelle samfundsudvikling og hævder, at samfundet er sygdomsramt: det er - mere præcist - blevet inficeret af et kompetencevirus og en heraf følgende udtørring af åndslivet. Han siger: »Det er et af de bizarre træk ved vort samfund, at aldrig har mennesker været mere beslaglagt af krav og nødvendigheder, og alligevel er det manglen på nødvendighed og mening, der plager det moderne menneske. $\varkappa^{1}$ På den baggrund efterlyser han en offentlig opinion, der opstiller alternative uddannelsesbilleder som modvægt til den rationelle mål-middel tænkning - uddannelsesbilleder, som hviler på den grundantagelse, at menneskelivet indeholder en dybdedimension, der ikke kan begribes inden for en videnskabelig, fornuftsmæssig forklaringsramme, hvorved vi får bragt fokus på betydningen af at forankre undervisning i en samtale om eksistentielle - metafysiske - problemstillinger - det, som K.E. Løgstrup kalder de uløselige spørgsmål, såsom: Hvad er meningen med livet? Hvad vil det sige at være menneske? Hvordan definerer vi det gode liv?

Det er præcist her, Regner Birkelund kommer ind i billedet med sin bog Livs-Oplysning. Regner Birkelund, der er ansat som lektor ved Institut for Sygeplejevidenskab ved Aarhus Universitet, har en Ph.D.-grad i pædagogik og har blandt andet deltaget $i$ et 4-årigt tværvidenskabeligt forskningsprojekt under betegnelsen »Voksenuddannelse, folkeoplysning og demokrati«. Bogen Livs-Oplysning er blevet til på baggrund af en mindre omredigering af hans Ph.D.-afhandling, som han forsvarede i 1998. Med denne bog præsenterer han os for det, vi efterlyser, nemlig et uddannelsesmæssigt modsvar til tidens rationelt funderede uddannelsestænkning. Birkelunds pædagogiske ærinde er, med baggrund i N. F. S. Grundtvig og K. E. Løgstrup og deres modernitetskritik, at formulere et korrektiv til den øgede tendens til at opprioritere de videnskabsbaserede og teoretiske kundskaber inden for uddannelsesområdet. Herfra skal det spontant lyde: Tak for det! Den pædagogiske debat er blevet beriget med et vigtigt og meget smukt komponeret bidrag. Der er i sandhed tale om opbyggelig læsning. Og man kan kun sige: må så mange mennesker som muligt stifte bekendtskab med denne bog og lade sig inspirere af dens 
tanker. Det kunne verden nok trænge til. Bogen føjer sig nemlig ikke blot ind i den pædagogiske debat, den er livsvedkommende på et meget fundamentalt - eksistentielt - niveau. Dertil kommer, at leder man efter en introduktion til Grundtvigs pædagogiske ideer og til Løgstrups etik- og æstetikforståelse, så er dette bogen. Birkelund er en sand mester ud i formidlingens kunst; han evner - som få - at få svært tilgængeligt og kompliceret stof til at fremstå levende og let forståeligt.

Birkelunds interesse er rettet mod en problemstilling af almen pædagogisk karakter og relevans, nemlig hvordan man forener faglig uddannelse med menneskelig dannelse (s. 9). Hans undersøgelse af dette spørgsmål er centreret omkring et konkret eksempel inden for sygeplejen - et såkaldt pædagogisk eksperiment, der fandt sted på Testrup Højskole, og som strakte sig over ca. 50 år fra 1927-1975. Eksperimentet, der gik under betegnelsen »Forskolen i Højskolen« bestod i at kombinere sygeplejeuddannelse med højskolens livsoplysning (s.47). Formålet med dette forskole-kursus til sygeplejeskolen, som forløb over fem måneder, var at undervise de vordende sygeplejersker $i$ almindelige højskolefag og sygeplejefag; gennem undervisning og socialt samvær ville man: »...fremme de unges Udvikling og derigennem hjælpe dem til at blive oplyste, dygtige og gode Mennesker.« (s. 44) Idealet var en undervisning, som var drevet af lyst og fri modtagelighed, og hvor således ikke kun fornuften, men også hjertet, var involveret. De to hovedskikkelser, der stod i spidsen for dette eksperiment, og som virkeliggjorde og personificerede de pædagogiske ideer, var Maren Grosen og Ingrid Kaae, som begge har været forstandere på Testrup Højskole. Bogens første del er således centreret omkring disse to kvinder og deres enestånde livsmission, og Birkelund formår på mesterlig vis at få de to kvinder til at træde levende frem, så deres store menneskelige format stråler i smukt flor. Man forstår, hvilke enestående forbilleder og eksempler, de har været. Og samtidig forstår man, hvilket tab det har været, at vor tids uddannelsestænkning ganske har underkendt betydningen af det levende forbillede, den store personlighed og læring gennem eksempel - at den så entydigt har lært os, at evnen til at kritisere og pille fra hinanden er langt vigtigere end evnen til at beundre og bøje sig for storhed.

Karen Grosen og Ingrid Kaae gik til kamp mod den teoretiske kundskabsindlæring ud fra den grundholdning, at det er den menneskelige oplysning og dannelse, der er det endelige mål i uddannelsen (s. 45). Og herunder er synspunktet, at de menneskelige - etiske - værdier, som skal bringes til udtryk i sygeplejen såsom omsorg, medmenneskelighed, åbenhed, sans for fællesskabet, ikke kan læres via teoretisk boglig viden. Forudsætningen for at disse værdier kan komme til udtryk, er, at de har rod i en fundamental glæde ved livet. Derfor bliver højskolens primære opgave at formidle livsglæde (s. 62). Det medie eller sprog, som skal vække livsglæden og åbne vore øjne for de menneskelige værdier, er det æstetisk-poetiske udtryk såsom sang, musik, 
skuespil, naturoplevelser og den klassiske litteratur, da vi herigennem får billeder på livet og livets grundsandheder; kunsten åbner, som Maren Grosen siger, vore øjne for: "...en verden af skønhed, godhed, retfærdighed og kærlighed..." (s. 71) - en verden, hvor der er noget, som er større og mere værdifuldt end det enkelte individ, hvor fællesskab, sammenhæng og den følelsesmoessige forståelse af livet er i højsædet. Tænk på H.C. Andersens eventyr Snedronningen, hvor vi ser et af de fineste eksempler på det poetiske sindelag: at kun med hjertet kan man se "rigtigt" - kun med følelsernes sprog lader livets sammenhæng sig tyde. Det er dette sindelag, som Ingrid Kaae appellerer til, når hun siger: "Vi vil så gerne, at vore elever skal have tid til at undres, at gå "ud en sommerdag at høre fuglesang, som hjertet kunne røre», for det er den slags oplevelser, der gør sindet frodigt..." (s. 73).

Birkelunds ambition er at vise, at der netop i dette pædagogiske eksperiment på Testrup Højskole er noget helt afgørende at hente for den aktuelle uddannelsestænkning i en tid, hvor forandring og udvikling er blevet ophøjet til øverste værdi, og hvor den teknologiske logik - herunder effektivitets-, nytte- og rationaliseringsovervejelser - får større og større plads på bekostning af den menneskelige dannelse. Det er en problematik, som inden for sygeplejeuddannelsen har fået særlig relevans og aktualitet i lyset af at uddannelsen i 1990 - med en ministeriel bekendtgørelse - er blevet gjort til en studiebaseret videregående uddannelse med en heraf følgende opprioritering af den teoretiske kundskabs- og videnskabsmæssige del (s. 15).

Med udgangspunkt i en forståelse af sygeplejen som et praktisk fag, hvor den medmenneskelige dimension - og herunder omsorgen - spiller en afgørende rolle, ønsker Birkelund således at finde svar på, hvordan man bedst tager vare på den medmenneskelige dimension inden for sygeplejen. Svaret går gennem Maren Grosen og Ingrid Kaae, og herfra trækkes de idéhistoriske tråde tilbage til Grundtvig. Birkelund vil med andre ord demonstrere, at det er Grundtvigs pædagogiske tanker og herunder hans livsoplysningsbegreb, der ligger til grund for eksperimentet i Testrup. Således er bogens 2 . del en indføring i Grundtvigs pædagogiske ideer og en dokumentation af Testrupeksperimentets grundtvigske ånd, hvor vi făr en meget levende formidlet analyse af det grundtvigske livsoplysningsbegreb, som er baseret på et opgør med oplysningsfilosofiens - det vil sige Kants - videns- og oplysningsopfattelse, hvor oplysning entydigt defineres som et forstands- og fornuftsbaseret begreb, forankret $i$ en forestilling om mennesket som et selvstændigt og uafhængigt væsen, hvis erkendelse kun erbåret af fornuften. I opposition hertil argumenterer Grundtvig ud fra et skabelsesteologisk perspektiv og hævder dermed, at mennesket ikke er sin egen skaber; det er skabt og dermed givet et grundlag for erkendelsen. Livsoplysning ifølge Grundtvig er således oplysning om det liv, vi har fået skænket - det liv, som i selve sit væsen er underligt og gådefuldt, $\mathrm{og}$ som derfor ikke kan forklares eller begribes inden for en rationel 
optik (s.126f). Livet indeholder med andre ord et dybdelag, der transcenderer fornuften. I pædagogisk henseende bringes disse tanker til udfoldelse med begrebet "Skolen for Livet «, der netop er formuleret som et korrektiv til den teoretiske, tvangsmæssige og eksamensrettede kundskabsmeddelelse - det, som Grundtvig kalder »Papirs-Oplysning«, og som han samlet set lader gå under betegnelsen »Skolen for Døden« (s. 131). Formålet med undervisning og herunder med livsoplysning er - som også Maren Grosen og Ingrid Kaae gjorde til deres budskab - at styrke livsglæden og livsmodet, hvorved lysten og frivilligheden skal være de læringsmæssige drivkræfter. Dette grundtvigske hovedbudskab - der også kan stå som pædagogisk motto for eksperimentet $\mathrm{i}$ Testrup - får sit mest koncentrerede udtryk i sangen: »Nu skal det aabenbares", hvor det lyder: »Og han har aldrig levet, som klog paa det er blevet, han først ej havde kær! . $^{2}$

Et bærende element i Grundtvigs livsoplysningsbegreb er, at vi kun kan fornemme livets dybdedimension gennem en følelses- og oplevelsesmæssig involvering. I opposition til Kant, baserer Grundtvig sig på den grundantagelse, at følelserne, på linje med fornuften, er erkendelsesbærende, og derfor må undervisning også være rettet mod mennesket som et følelses- og oplevelsesvæsen (s. 142). Det er her, Grundtvigs begreb det historisk-poetiske kommer ind i billedet - et begreb, der allerede er blevet foregrebet under referencen til Maren Grosen og Ingrid Kaae. I modsætning til det intellektueltbeskrivende sprog, der formidler via fornuften og henvender sig til vores analytiske forståelse, så henvender det poetiske sprog sig til menneskets fantasi og indlevelses- og forundringsevne. Poesien og kunsten levendegør og visualiserer livets grundvilkår såsom at livet er mageløst, at vi er indplaceret i historien og dermed en del af noget større (s. 144). Modsat Kant, mener Grundtvig således, at det er historien, der er vores erfaringskilde; det er herudfra, vort liv får mening og sammenhængskraft. Og dermed bliver livsoplysningens opgave - via poesien - at rodfæste os i den historie, vi alle er en del af.

Med begrebet det historisk-poetiske som omdrejningsakse leder Birkelund os i bogens tredje - og sidste - del fra Grundtvig frem til Løgstrup. Og det er så at sige her, den genuint birkelundske pointe kommer til udtryk: han baserer sig på den opfattelse, at Løgstrups etik- og æstetikforståelse er en form for videreudvikling eller eksplicitering af Grundtvigs livsoplysningstanker (s. 176). Og således lader han Løgstrup give nutidigt liv eller aktualitet til de grundtvigske livsoplysningideer - og herunder til eksperimentet i Testrup. Man kan være uenig med Birkelund og mene, at der i Løgstrups forfatterskab mangler eksplicitte Grundtvig-referencer som belæg for denne tese; men læser man Løgstrups artikel »Højskolens nye fronter « (Johannes Rosendahl (red.), Højskolen til debat; Gyldendal, København 1960, s. 212); så synes ånden fra Grundtvig at være meget markant. Hvorom alting er: Birkelunds tese er interessant, og den gennemføres flot. 
Ligesom Grundtvig baserer Løgstrup sit livssyn på skabelsestanken: han opfatter verden som skabt og dermed som noget, der er os givet. I og med dets skabthed har livet - fra begyndelsen - fået en bestemt form og en særlig værdi og er dermed så at sige etisk i selve sin væren. De særlige værdier, der således bærer vort liv, er de suveræne livsytringer, dvs. tillid, talens åbenhed, barmhjertighed og medfølelse (s. 179). Mennesket har så at sige fået livet skænket, for at det skal realisere sig i livsytringerne. Livsytringerne bestemmer med andre ord mennesket i dets menneskelighed - i dem er vi umiddelbart os selv (heraf kommer, at de er suveræne). Endvidere er de spontane, hvilket vil sige, at de sætter sig igennem uden om vores vilje. Det helt centrale - også i relation til sygeplejen - er, at livsytringerne netop peger hen på omsorgen for næsten (s.182) - mennesket handler med andre ord etisk ved at lade livsytringerne - og dvs. livet selv-strømme spontant og ureflekteret igennem sig hen mod sit medmenneske. Således ligger der med dette etik-syn en appel til den modtagende, kontemplative side i mennesket - en opfattelse, der også reflekteres i Grundtvigs tænkning.

Da det hører det menneskelige samliv til, at vi altid møder hinanden med tillid - tilliden er som sagt et af de menneskelige grundvilkår - så lever vi dermed også altid i en udleverethed til hinanden - det er så at sige et ontologisk faktum, som vi ikke kan vriste os fri af - vi har, om vi ønsker de eller ej, altid noget af et andet menneskes skæbne i vore hænder. Af denne udleverethed udspringer en uudtalt fordring om at tage vare på den andens liv, og: »... siddes den uudtalte fordring overhørig, kan det alt efter situationen få de alvorligste konsekvenser. « (s. 183). Lignelsen om den barmhjertige samaritaner kan i denne sammenhæng åbne vore øjne for disse grundlæggende livsvilkår.

Med baggrund i denne livs- og menneskeopfattelse er det - ifølge Løgstrup - livsoplysningens opgave at give næring til de suveræne livsytringer og i forlængelse heraf at holde den selviskhed og det aggressionselement, der er forbundet med behovene, i skak (s. 217).

Den kilde, hvorfra etikken og livsytringerne skal hente sin energi-det, der med andre ord skal appellere til den uselviske og selvforglemmende livsholdning - er æstetikken eller sansningen - det, der ikke kan indsættes i nytte- eller behovscentrerede kategorier. I sansningen bevæges vi netop af noget, der ligger uden for os selv, af noget, som vi ikke kan erobre eller beherske (s. 194f). Her er vi så at sige modtagere af livet selv, og det er en fornemmelse, der kan vækkes via alle former for kunstneriske udtryk, såsom maleriet, film, musik, sang og naturoplevelser som f.eks. det at opleve en funklende stjerneklar himmel, hvor man oplever sin egen indfældethed i en sammenhæng, der rækker ud over én selv. Det æstetiske udtryk, som således tjener til at give mennesket en oplevelse af helhed og sammenhæng, ønsker Løgstrup, på linje med Grundtvig, at gøre til didaktisk omdrejningspunkt inden for undervisningsverdenen, for som han siger andetsteds: ॥Vi kan simpelthen ikke leve af 
at konstatere og formulere, systematisere og teoretisere...Vi er nu engang først og sidst følelsesbestemte...væsener... « ${ }^{3}$

Således vil Løgstrup med sit begreb om tilværelsesoplysning bringe opmærksomhed til den side af mennesket, der ligger uden for de skabende forhold - den del af livet, vi ikke kan beherske. Hermed får vi, som hos Grundtvig, præsenteret et uddannelsessyn, der står som led i en bred kultur- og modernitetskritik.

Med det livs- og uddannelsesperspektiv vi nu har fået præsenteret, er vi naturligt fremme ved den nyeste bog, som Birkelund har redigeret. Det er en antologi, som bærer titlen Eksistens og livsfilosofi, hvori en række fremtrædende danske - og et par svenske - forskere præsenterer centrale tanker hos nogle af de mest epokegørende danske, svenske, tyske og franske livsfilosoffer.

Dette værk er i vid udstrækning ude i samme ærinde som bogen Livs-Oplysning; det henvender sig til samme målgruppe og bevæger sig grundlæggende set inden for samme før-videnskabelige livsanskuelsesramme, idet det baserer sig på den grundantagelse: »... at livet er mere end teorier om livet, at der altid er noget tilbage, når videnskaben med sine nok så raffinerede metoder har forsøgt at kortlægge tilværelsen. «(s. 7) Det er således dette mere - dette livs-overskud - som livsfilosofien forsøger at indkredse, og det er dette livsperspektiv, som Eksistens og livsfilosofi ønsker at gøre relevant i forhold til uddannelses- og social- og sundhedsområdet. Der er - med andre ord - igen tale om en bred modernitetskritik, et opgør med oplysningstidens rationelle verdens- og menneskesyn, dens fokus på det mål-og fremadrettede, samt dens centrering om det enkelte individ og de individuelle behov.

I forordet fremgår det, at bogen som helhed orienterer sig ud fra det synspunkt, at det livsfilosofiske perspektiv i særdeleshed er relevant inden for pædagogikken og social- og sundhedsområdet, fordi man her arbejder med mennesker, som har brug for opmærksomhed, støtte og omsorg; og således gælder det, at man inden for denne verden altid holder noget af et andet menneskes liv i sine hænder. Der er så at sige et liv, der skal tages vare på. Med afsæt i denne løgstrupske etik-forståelse vil bogen således sætte fokus på nogle af de livsvilkår, vi lever af og på, som former eller bærer det menneskelige samliv, og som vi ikke kan få hold på af videnskabelig vej. Hertil hører livsfænomener som tillid, livsglæde, livsmod, kærlighed, tro, tillid, skyld og sorg (s. 8). Med disse hovedpunkter fra introduktionen bliver det således tydeligt, at der er tale om en videreførelse eller genoptagelse af livsoplysningstemaerne, og dermed tegner der sig en interessant mulighed for at pege på en afgørende forbindelse mellem de to begreber livsoplysning og livsfilosofi.

Bogen er inddelt i tre hovedafsnit, hvor det første er viet til 'Livsfilosofien og kunsten'; med kunst refereres der her til skønlitteraturen, og vi præsenteres for tre skelsættende forfattere, der via skønlitteraturen behandler livsfiloso- 
fiske temaer. Det drejer sig om Fjordor Dostojevskij (præsenteret af Søren Matthiessen), Karen Blixen (Elisabeth Dons Christensen), og endelig Jakob Knudsen (Svend Bjerg).

Andet hovedafsnit bærer titlen 'Svenske og danske livsfilosofiske tænkere', hvor man har valgt at introducere N. F. S. Grundtvig (Jørgen Carlsen), Søren Kierkegaard (Jørgen Husted), Ludvig Feilberg (Mogens Pahuus), K. E. Løgstrup (Regner Birkelund), Erik Gustaf Geijer (Harry Aronson) og Ellen Key (Bosse Bergstedt).

Det tredje - og sidste - hovedafsnit går under den samlede titel 'Tyske og franske livsfilosofiske tænkere'; her præsenteres Martin Heidegger (Ole Fogh Kirkeby), Hans Lipps (Svend Andersen), Hannah Arendt (Anne Marie Pahuus), Martin Buber (Mogens Pahuus), Henri Bergson (Peter Kemp), Emmanuel Lévinas (Henrik Vase Frandsen) og endelig Mourice MerleauPonty (Jacob Dahl Rendtorff).

Som man kunne sige om bogen Livs-Oplysning, så er der igen tale om en vigtig bog. Mig bekendt findes der ikke lignende bøger, som under en samlet titel Livsfilosofi præsenterer en række (livs)filosoffer og deres centrale tanker - med henblik på en dialog med uddannelses-, social- og sundhedsområdet. Det er en stor lykke at, der er flere, som ønsker at udfordre tidsånden med et alternativt livs- og uddannelsesbillede. Det er også alt i alt inspirerende læsning - de enkelte bidrag er yderst læseværdige; de vækker til eftertanke, idet de hver på deres måde kaster et kritisk perspektiv på tiden og det oplysningsprojekt, som vi alle er børn af. Man får lyst til at gå til de enkelte forfattere selv for at blive klogere på deres tænkning, og dertil bliver man rigtig godt hjulpet på vej, idet hvert kapitel er forsynet med mange gode henvisninger til de centrale værker inden for primær- og sekundærlitteratur. Men bogen har dog sine svagheder, og de dukker op allerede i forordet.

Begrebet livsfilosofi er - som Ole Fogh Kirkeby skriver i sit afsnit om Martin Heidegger - et flertydigt og temmelig ubestemt begreb (s. 196). Og det er et problem, som dette værk lider under. Der mangler en mere uddybet og præcis - indledende - begrebsafgrænsning af begrebet livsfilosofi, som får det til at stå helt klart, hvad der præcist samler de her præsenterede filosoffer. Dernæst, så er det uklart, hvordan de to begreber, der indgår i titlen - eksistens og livsfilosofi - relaterer sig til hinanden. Som nævnt får vi i forordet at vide, at det livsfilosofiske står for »det mere« eller det overskud i tilværelsen, som videnskaben ikke kan blotlægge. Det vil med andre ord sige, at det, der forener de enkelte tænkere, er en enighed om at undsige fornuften som den instans, der har det sidste ord i bestemmelsen af, hvad livet og mennesket er for noget. Men spørgsmålet er, om det er en fyldestgørende definition på begrebet livsfilosofi. Jeg vil for eksempel - for at gå direkte til sagen - sætte spørgsmålstegn ved det hensigtsmæssige $i$ at kalde både Løgstrup og Kierkegaard for livsfilosoffer. Man vil i hvert fald - hvis man gør det - nemt komme til at snyde 
uindviede læsere for en helt afgørende filosofisk pointe, der først rigtig tydeliggøres ved at, sondre mellem to begreber: nemlig livsfilosofi og eksistensfilosofi. For at illustrere denne forskel vil jeg - kort - henvise til Mogens Pahuus og hans bog "holdning og spontaneitet«, hvor han på en meget opklarende måde sondrer mellem de to begreber. Her peger han på - og jeg citerer frit - at det er kendetegnende for livsfilosofien, at den baserer sig på den grundantagelse, at mennesket er mere end et skabende og selvudfoldende væsen. Livsfilosofien er primært interesseret i mennesket som selvforglemmende og selvhengivende væsen, der spontant er optaget af verden og andre mennesker. Grundtanken i eksistensfilosofien er, derimod, at mennesket er et frit handlende eller selvstændigt væsen, der fører sin egen tilværelse, idet det forholder sig til ydre og indre påvirkninger. ${ }^{4}$ Eksistensfilosofien er således fokuseret på mennesket som et skabende væsen; den baserer sig på den opfattelse, at den enkelte selv skal kvalificere livet og give det alvor og mening. Det er med andre ord subjektivitetens perspektiv, der her gøres gældende. På den måde har vi at gøre med to radikalt forskellige filosofiske traditioner, som godt nok begge gør op med fornuftens autoritet, men som er meget uenige i, om det er individet eller fællesskabet, der bør tages udgangspunkt $i$, om livets mening er livet iboende, eller om det er noget, som mennesket selv skal skabe. Jeg mener således, at man eksplicit bør fremhæve forskellen på disse to filosofiske traditioner og pege på, at der er ét spor, som tegnes af navnlig Grundtvig, Jakob Knudsen, Ludvig Feilberg og Løgstrup.

Som højskoleforstander Jørgen Carlsen skriver i et meget veloplagt bidrag om Grundtvig, hvor han bruger Grundtvigs tanker som korrektiv til vor tids jagt på at følge med udviklingen, så er den bærende pointe i Grundtvigs livsperspektiv, at vi skal besinde os på, hvad vi bliver båret af - at der i livet er indlagt værdier (s. 83). Som nævnt ligger Løgstrup på linje med denne holdning, hvilket Regner Birkelund også klargør i sit bidrag, hvor han meget træffende betegner Løgstrups etik som en tilbageholdenhedens etik (s. 159), der betoner livets iboende værdi og skønhed, fællesskabet, helheden, den menneskelige interdependens. Også Jakob Knudsen kan placeres inden for samme tradition. Dr. theol. Svend Bjerg giver en fortræffelig og meget læsevenlig indføring i Jakob Knudsens tænkning, som han samler under livsmottoet: at voere er vigtigere end at ville (s.49). Og det er netop disse livsfilosofiske perspektiver, som ligger til grund for Grundtvigs og Løgstrups livsoplysningsbegreber (jf. bogen Livs-Oplysning).

Når man så bevæger sig fra Grundtvig og Løgstrup til Kierkegaard, som præsenteres af filosoffen Jørgen Husted, ja så foretager man et såkaldt filosofisk sporskifte. Husted præsenterer en meget spændende og kontroversiel læsning af Kierkegaard, hvor han ud fra etikerens brev fra Enten-Eller, tolker Kierkegaard inden for en filosofisk - humanistisk - horisont. I spørgsmålet om livets grundlæggende eksistentielle spørgsmål er Kierkegaards perspektiv 
og fokuspunkt herunder et ganske andet sted end Løgstrups og Grundtvigs. I modsætning til Løgstrup er Kierkegaards pointe, at det er det enkelte menneske, der står over for den opgave - selv - at skulle kvalificere og give alvor til sit liv. Her får vi således introduceret det førnævnte subjektivitetens perspektiv (s. 103) og i forlængelse heraf de bærende eksistentielle kategorier i Kierkegaards etiske tænkning, det vil sige begreber som selvet, det ideale selv, selvovertagelse, selvbestemmelse, selvets afgørelse og selvets virkeliggørelse. Hvor Løgstrup taler om at glemme sig selv, taler Kierkegaard om at realisere eller virkeliggøre sig selv (s. 121). Kierkegaard vil jeg på den baggrund betegne som eksistensfilosof - også i lyset af, at Løgstrup i bogen "Opgør med Kierkegaard " jo netop direkte kritiserer Kierkegaard - og den eksistensfilosofiske linje - for ikke at tilkende livet en værdi uafhængigt af det enkelte menneskes subjektive valg.

For nu at holde tråden til livsoplysningsbegrebet, så kan herunder tilmed nævnes, at Husted i forlængelse af sin filosofiske Kierkegaard-læsning også placerer Kierkegaard i en livsoplysningstradition. Det gør han for eksempel i artiklen 'Livsoplysning i filosofisk perspektiv', hvor han på Kierkegaards vegne siger om begrebet livsoplysning, at det er: »...samtalen om hvordan et menneske bør leve sit liv «. ${ }^{5}$ Og her illustreres det med al tydelighed, at denne livsoplysningsdefinition - i modsætning til Løgstrups og Grundtvigs - tager sit udgangspunkt i det enkelte menneske og den individuelle afgørelse og ikke i fællesskabet eller i en - i livet - iboende værdi. Livsoplysning ifølge Kierkegaard bør således nærmere siges at have rod i et eksistensfilosofisk end i et livsfilosofisk perspektiv. På denne kierkegaardske linje vil man for eksempel også kunne placere Karen Blixen.

Jeg mener, det er afgørende, at man kan orientere sig ud fra disse to filosofiske spor - også når man skal tage stilling til, hvilket af de to perspektiver, man ønsker at fremme inden for den pædagogiske verden - om man primært vil styrke sansen for det mellemmenneskelige eller om man i højere grad vil appellere til, at det enkelte individ skal bringes til klarhed over sig selv.

I tæt tilknytning hertil har bogen det problem, at dens referencer til det pædagogiske felt er for utydelige - ja, for det meste direkte fraværende. Det fremgår i for ringe grad, hvilke tanker, bidragyderne har gjort sig om, hvordan man kan integrere det livsfilosofiske perspektiv i pædagogikken og i forhold til social- og sundhedsområdet? Og i øvrigt ved man heller ikke rigtigt, om det egentligt er en berettiget forventning at stille til bogen. Dette problem falder igen i nogen grad tilbage på forordet, som ikke formulerer en klar ambition eller målsætning. Man kunne for eksempel her have stillet to eller tre spørgsmål, som hvert enkelt bidrag skulle svare på eller reflektere over; det ville $\mathrm{i}$ højere grad have vidnet om et fælles ærinde, og det ville have givet bogen et større enhedspræg. Bogen favner meget bredt: der er alligevel langt fra Grundtvig til Merleau-Ponty, og hvorfor ikke fortrinsvist - i denne her 
sammenhæng - blive i det danske? Det kan i hvert fald synes lidt underligt, at man er gået uden om to så store danske tænkere som Harald Høffding og Vilhelm Grønbech.

Men hvorom alting er: jeg er stadig begejstret; det er en bog, der vækker til eftertanke - en bog fyldt med sympatisk og livsbekræftende tænkning.

Noter

1. Riis-Søndergaard, Laust, 'Kompetencevirus', i Højskolebladet, nr. 13,23. august 2002, s. 2.

2. Grundtvig, N. F. S., 'Nu skal det aabenbares', i P. A. Rosenberg (red.), Udvalgte Vorker Bd. I., Forlaget Danmark, København 1930, s. 362.

3. Løgstrup, K. E., 'Højskolens nye fronter', i Johannes Rosendahl (red.), Højskolen til debat, Gyldendal, København 1960, s. 212.

4. Se Pahuus, Mogens, 'Holdning og spontaneitet. Pædagogik, menneskesyn og værdier', i KvaN, Et tidsskrift for læreruddannelsen og Folkeskolen, Århus 1997, s. 8.

5. Husted, Jørgen, 'Livsoplysning i filosofisk perspektiv', i KvaN, årg. 19, nr. 55 (1999), s. 11. 